\title{
SEISMIC BRACING PERFORMANCE OF PLASTERBOARD TIMBER WALLS
}

\author{
Angela Liu ${ }^{1}$ and David Carradine ${ }^{2}$
}

(Submitted November 2018; Reviewed December 2018; Accepted January 2019)

\begin{abstract}
The goal of this study is to develop a racking model of plasterboard-sheathed timber walls as part of the efforts towards performance-based seismic engineering of low-rise light timber-framed (LTF) residential buildings in New Zealand.

Residential buildings in New Zealand are primarily stand-alone low-rise LTF buildings, and their bracing elements are commonly plasterboard-sheathed LTF walls. It is an essential part of performance-based seismic designs of LTF buildings to be able to simulate the racking performance of plasterboard walls. In this study, racking test results of 12 plasterboard walls were collected and studied to gain insight into the seismic performance of plasterboard-sheathed LTF walls. The racking performance of these walls was examined in terms of stiffness/strength degradation, displacement capacity, superposition applicability and failure mechanisms. Subsequently, a mathematical analysis model for simulating racking performance of LTF plasterboard walls is developed and presented. The developed racking model is a closed-form wall model and could be easily used for conducting three-dimensional non-linear push-over studies of seismic performance of LTF buildings.
\end{abstract}

\section{INTRODUCTION}

Performance-based seismic design of building structures has significantly advanced over the last decade. The essence of performance-based seismic design of building structures is to design a building structure for multiple performance requirements such as damage controls.

New Zealand (NZ) has a performance-based code environment. However, the current seismic design standards are generally prescriptive and were developed primarily to achieve life safety at ultimate limit state (ULS) [1, 2]. Earthquake damage observed in recent earthquakes showed that the building structures designed to modern codes, although likely to achieve life safety in an event equivalent to the ULS intensity, often had significant damage. It is often not clear what performance levels, except life safety, could be expected of the building structures designed to modern seismic codes.

While there have been significant research efforts on performance-based seismic designs of reinforced concrete building structures, there has been limited research on LTF buildings and nearly no efforts on LTF buildings as commonly built in NZ.

Most of residential buildings in NZ are low-rise LTF buildings. Seismic designs of LTF residential buildings in NZ largely follow the prescriptive standard NZS 3604 Timber-framed buildings [3]. NZS 3604 has an engineering basis [4] and its seismic design actions are derived using an elemental forcebased approach. The engineering basis of NZS 3604 is significantly less vigorous than that of other structural systems. For instance, NZS 3604 has no clarification on how capacity design philosophy was implemented. The ductility of 3.5 assumed in deriving the seismic demand of a subject building was not validated against the energy-dissipating capacity of LTF bracing walls. The effect of stiffness incompatibility of different walls due to different lengths or different configurations or different hold-down means on the seismic performance of the building was not studied either. As such, the uncertainties associated with the estimation of residential building response to severe earthquake ground motions could be substantial when compared to those associated with the response and performance of reinforced concrete or steel structures.

In the 2010/11 Canterbury earthquake sequence, residential LTF houses achieved the New Zealand Building Code objective of "life safety". However, earthquake damage observed to LTF buildings was unprecedented. Figure 1 shows the significant damage observed on some modern plasterboard-sheathed LTF walls in the Canterbury earthquake sequence [5]. The financial losses associated with LTF residential buildings in this earthquake sequence alone costed NZ over $\$ 30$ billion, about $18 \%$ of NZ GDP.

Clearly, there is a need for advancing performance-based seismic design of LTF buildings. The lateral seismic resisting systems of LTF residential buildings in NZ are primarily plasterboard sheathed timber walls. Seismic performance of LTF buildings in a major earthquake strongly depends on the bracing performance of this type of wall system. As such, a logical step to be undertaken is to obtain a better understanding of the bracing behaviour of plasterboard-sheathed LTF walls, and this is one of the objectives of this paper.

In the first part of this study, the seismic engineering characteristics of LTF residential buildings in NZ are examined. Then, seismic bracing performance of LTF walls as typical of $\mathrm{NZ}$ practice is examined, based on the available racking test results of proprietary LTF walls, in terms of strength/stiffness degradation, deformation performance, energy-dissipating capacity and superposition law. On this basis, a mathematical model representing the bracing behaviour of plasterboard LTF walls as typical of NZ practice is developed and presented. 

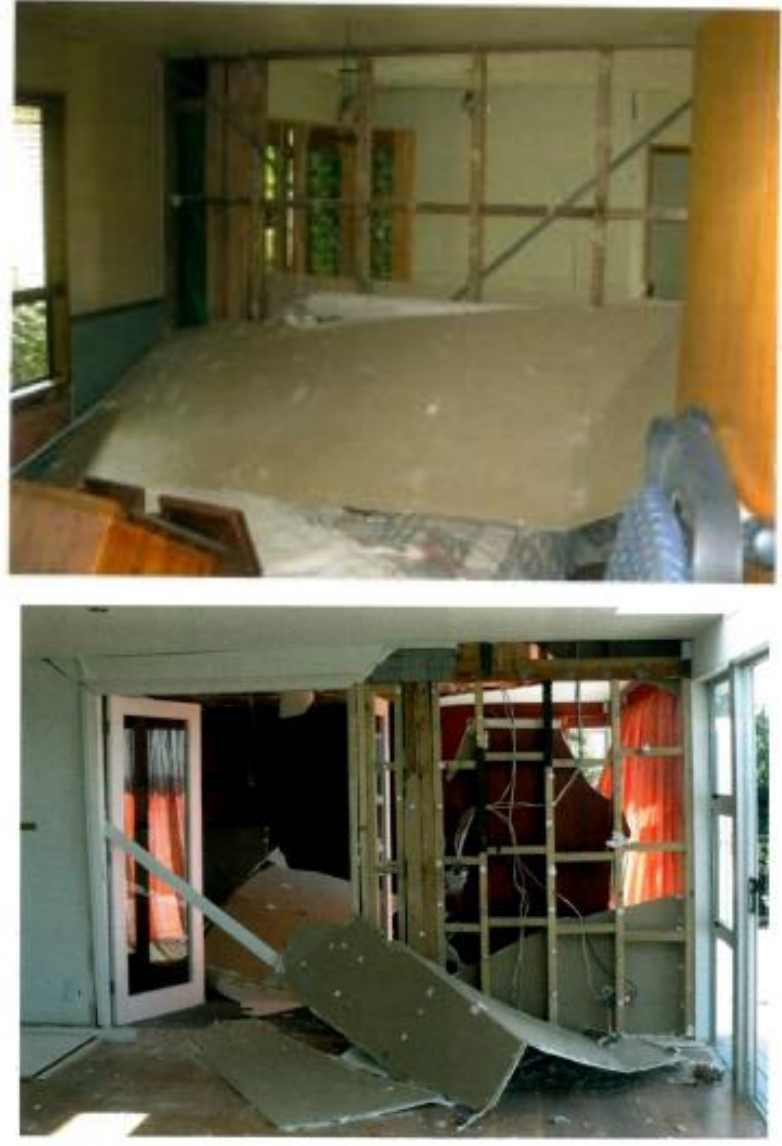

Figure 1: Damage observed in modern LTF buildings following 2010/2011 Canterbury earthquake sequence.

\section{SEISMIC ENGINEERING CHARACTERISTICS OF LOW-RISE LTF BUILDINGS IN NZ}

NZS 3604 has been developed for constructing simple low-rise LTF buildings. For typical LTF buildings, the lateral seismicresisting systems are plasterboard-lined LTF walls, and therefore, LTF buildings perform in earthquakes in a similar way to other wall structures. The plasterboard-lined LTF walls are also the gravity load-carrying systems. The lateral deflections experienced by these walls in design earthquakes would be small in comparison with the wall lengths. In addition, low-rise LTF residential buildings are light in nature, and subsequently, P- $\Delta$ effects usually are not significant enough to cause instability problems. Therefore, the LTF buildings of mainly NZS 3604 construction could easily achieve life safety requirement in design earthquakes.

One overseas study showed that the low-rise timber building did not collapse even when the storey drift reached more than $6 \%$ [6]. The construction of LTF buildings in NZ is similar to that in other countries except for the wall lining materials. Hence, the collapse potential of LTF buildings in NZ should be of similar magnitude as reported overseas. A storey drift of $6 \%$ is significantly higher than the ULS deflection limit, $2.5 \%$, as specified in the New Zealand seismic loading standard [7]. This means that the life safety requirement at ULS as per NZS 3604 is not relevant.

While LTF buildings have a low probability of collapse in earthquakes, they are vulnerable to earthquake damage, and their seismic performance varies markedly from building to building. Apart from the force-based approach, many other factors also contributed to the inconsistent seismic performance of LTF buildings as observed in the Canterbury earthquake sequence. For instance, LTF buildings often have significant structural weaknesses, such as irregular arrangement of bracing elements across the floor plan, stiffness/deformation incompatibilities of different bracing systems and less-effective floor diaphragms for distributing the seismic actions to different bracing systems across the building. Due to the presence of significant structural weaknesses, the seismic actions induced in different bracing systems can significantly deviate from a force-based theoretical prediction according to NZS 3604, causing greater variations of the expected seismic performance [1].

\section{Determination of Seismic Demand in NZS 3604:2011}

The seismic bracing demand was derived using an equivalent static method as recommended by NZS 1170.5, assuming a fundamental period of 0.4 seconds and a ductility of $\mu=3.5$.

The model used to derive the seismic demand in NZS 3604 is an elemental lumped mass model as shown in Figure 2 [4].

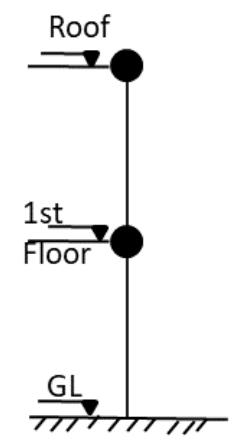

(a) Two-level building

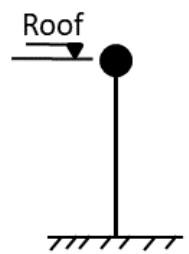

(b) Single-level building
Figure 2: Models used in deriving earthquake demand.

The governing equation for seismic base shear action is as follows:

$V=C_{d}\left(T_{l}\right) W_{t}$

where:

$V=$ horizontal seismic shear force at the base of the structure $C_{d}\left(T_{l}\right)$ is the horizontal seismic action coefficient derived by assuming a ductility of $\mu=3.5$ and a fundamental period of $T_{I}$ $=0.4$ seconds

$W_{t}$ is the seismic weight of the building.

The vertical distribution of seismic actions between levels has used the provisions of NZS 1170.5 as follows:

The seismic action distributed to floor level $i, F i$, is calculated from Equation 2 with an additional $8 \% \mathrm{~V}$ applied at the roof level:

$F i=0.92 V \frac{M i h i}{\sum_{1}^{n} M i h i}$

where:

$M i=$ seismic mass lumped at level $i$

$h i=$ height from the ground to floor level $i$ or roof

\section{Provision of Seismic Bracing Capacity}

For the provision of bracing capacity, NZS 3604 adopted the P21 test procedure [8] to evaluate the seismic and wind bracing capacity of proprietary LTF wall elements.

The P21 test is a slow cyclic racking test on a cantilever LTF wall element, and a horizontal load is applied at the top of the wall as a series of three displacement-controlled cycles to displacements of $\pm 9, \pm 15, \pm 22, \pm 29, \pm 36$ and $\pm 43 \mathrm{~mm}$. The test arrangement and the load protocol for a typical P21 test are respectively illustrated in Figure 3 and Figure 4. 


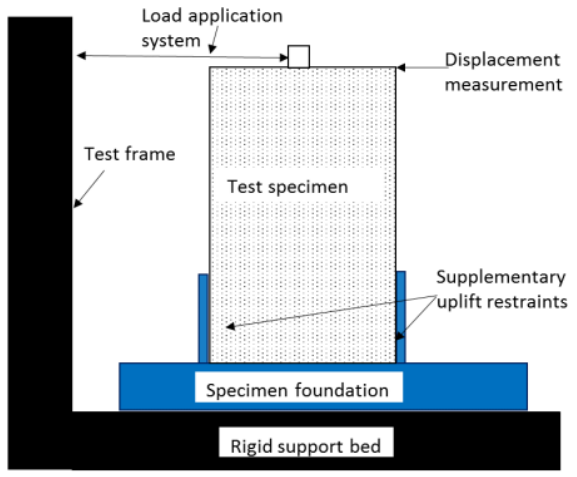

Figure 3: P21 test arrangement.

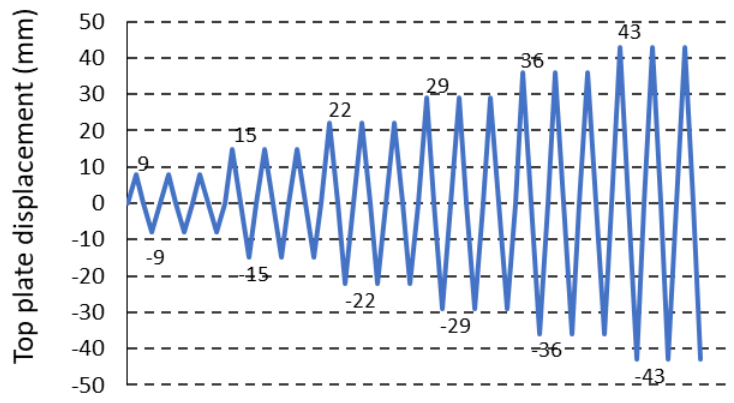

Figure 4: Load protocol used in P21 tests.

The P21 test procedure only requires that the applied load and the in-plane deflection be measured at the top of the specimen. The lateral displacement measured at the top of the specimen is the sum of all contributions from different deformation mechanisms including uplift at the wall base, screw slip and elastic deformation within the sheathing as well as the deformation of the frames.

The seismic rating of the wall element is determined from the fourth cycle force at an elected deflection level between $15 \mathrm{~mm}$ and $36 \mathrm{~mm}$, depending on when significant strength degradation occurs. P21 tests are often conducted on standard wall lengths, $0.4 \mathrm{~m}, 0.6 \mathrm{~m}, 1.2 \mathrm{~m}$ and $2.4 \mathrm{~m}$. The determined rating may be applied to walls up to twice the length of the tested specimens. If the rated LTF walls are used in a taller storey height situation, the seismic rating of the walls can be adjusted, based on the testified rating, and the adjusted seismic rating is equal to the rated seismic capacity multiplied by the ratio of $2.4 \mathrm{~m}$ versus the wall height in the intended applications.

\section{Seismic Bracing Design of Low-rise LTF Buildings}

With regards to the seismic bracing design of LTF buildings within the scope of NZS 3604, the designers just need to demonstrate that the total seismic bracing capacity provided for a building is at least equal to the total seismic demand as derived from NZS 3604.

In terms of bracing distribution requirements in NZS 3604, allowance is made for plan irregularity but not vertical irregularity. Plan irregularity of a building is accounted for by placing limits on the distribution of bracing lines and bracing elements, and these limits were established based on engineering judgement rather than scientific evidence.

It is noted that a study conducted recently showed that the permissible plan irregularity in NZS 3604 could amplify the seismic responses significantly in some areas [9]. To achieve seismic resilience of LTF buildings, NZS 3604 will need to be updated.

\section{EXAMINATION OF SEISMIC PERFORMANCE OF PLASTERBOARD TIMBER WALLS}

Many types of LTF proprietary timber wall bracing systems are used in low-rise LTF residential buildings in NZ, and over $90 \%$ of these bracing systems include plasterboard bracing walls. These timber wall bracing systems have identical timber framing, with the differences between them being the plasterboard sheets and fixing details, depending on the specification of plasterboard manufacturers. These systems need to be evaluated using P21 testing procedures before they are marketed in NZ and used for designs according to NZS 3604.

BRANZ has conducted many P21 tests on plasterboardsheathed timber walls. Most of these racking tests were conducted on plasterboard walls of standard lengths with the $1.2 \mathrm{~m}$ long walls being the most common.

P21 tests on plasterboard walls often show that the dominant deformation source of the wall, without allowing for uplift contributions, was the slip between plasterboard sheets and fasteners. Figure 5 shows the final appearance of a racking test of a $2.4 \times 2.4 \mathrm{~m}$ plasterboard wall, where two plasterboard sheets of $1.2 \times 2.4 \mathrm{~m}$ were used. The integrity of the entire plasterboard sheathing maintained throughout the test and the deformation mainly occurred due to the screw slips.
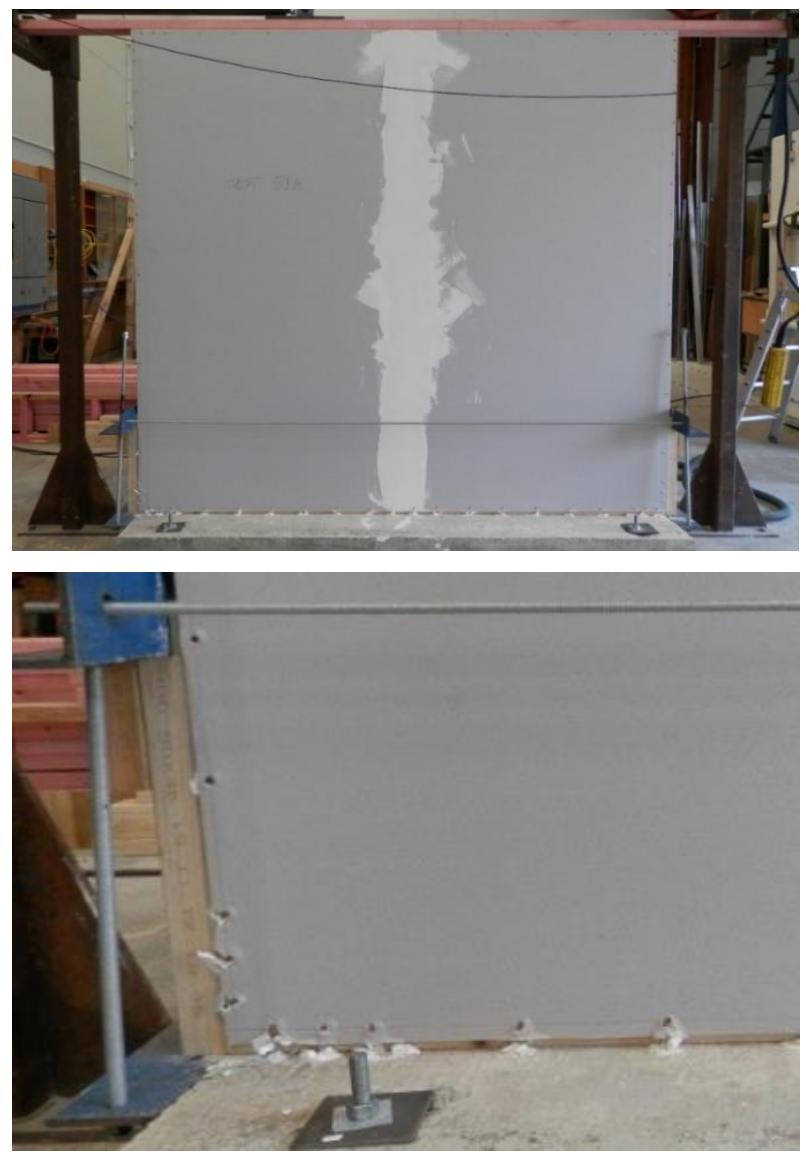

Figure 5: Final appearance after racking on a $2.4 \mathrm{~m}$ long plasterboard wall; overall view (top) and screw behaviour (bottom).

Figure 6 shows typical hysteresis loops obtained by P21 tests of plasterboard walls of different lengths. Often the seismic bracing capacities of plasterboard walls of different lengths are rated at different deflection levels. 


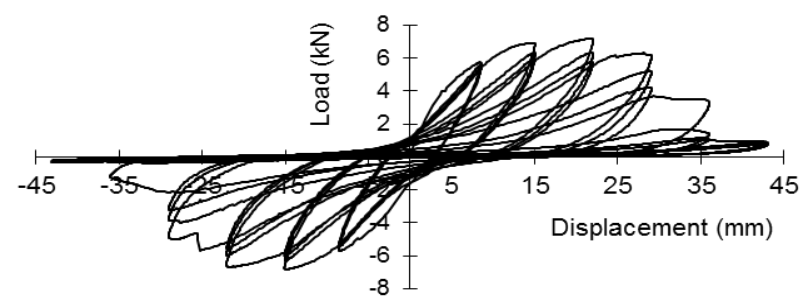

(a) 1.2 m long wall

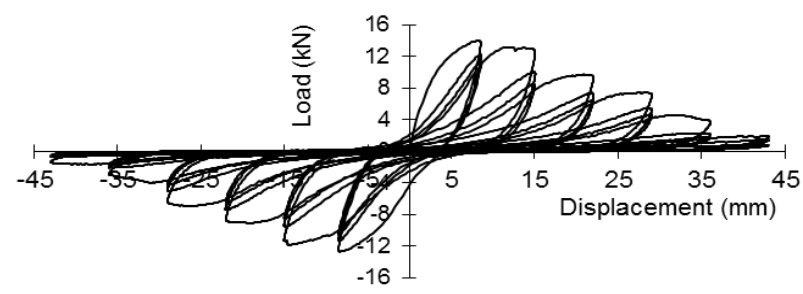

(b) 2.4 m long wall

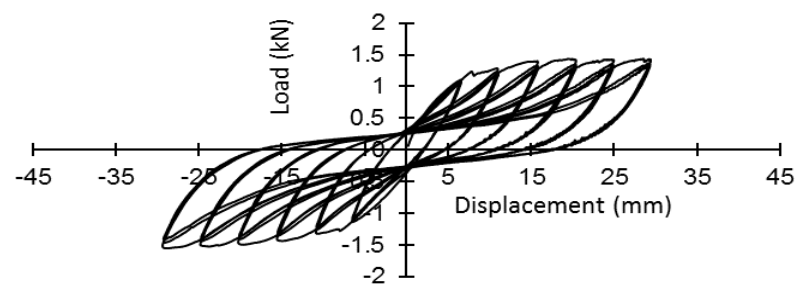

(c) 0.4 m long wall
In this study, a test data set of six pairs of P21 tests on plasterboard walls at BRANZ structures lab was collected. For all the tests included, timber frame construction was in accordance with NZS 3604 . The plates were connected to the studs with two $90 \times 3.15 \mathrm{~mm}$ power-driven nails, and there were no special hold-down devices at wall bases.

The two specimens in each pair were identical except that one was sheathed on one face and the other was sheathed on both faces. All these plasterboard walls were rectangular walls of $2.4 \mathrm{~m}$ high. The details of the test specimens and the racking capacities attained at three displacement levels, $8 \mathrm{~mm}, 15 \mathrm{~mm}$ and $22 \mathrm{~mm}$, are listed in Table 1 .

The discussions below focus on the

- $\quad$ effect of sheathing sheets on bracing performance of LTF walls

- characteristics of bracing performance of plasterboard walls

- mathematical models of LTF wall racking performance as typical of NZ plasterboard walls.

Effect of Sheathing Sheets on Bracing Performance of LTF Bracing Walls

LTF sheathed walls are the major lateral resisting systems in low-rise timber residential buildings overseas and in NZ, and therefore racking performance of these walls has been the subject of many studies $[10,19]$. However, LTF walls overseas use wood-based panel sheathing while LTF walls in NZ often uses plasterboard sheathing.

Figure 6: Racking performance of typical plasterboard timber walls of different lengths.

Table 1: Details of the collected P21 tests used in this study.

\begin{tabular}{|c|c|c|c|c|c|c|c|c|c|}
\hline \multirow{2}{*}{$\begin{array}{l}\text { Test } \\
\text { Names }\end{array}$} & \multirow[b]{2}{*}{ Length ( $\mathrm{m})$} & \multicolumn{2}{|c|}{$\begin{array}{c}\text { Plasterboard } \\
\text { thickness }(\mathrm{mm})\end{array}$} & \multicolumn{3}{|c|}{ Racking capacity (+) (kN) } & \multicolumn{3}{|c|}{ Racking capacity (-) (kN) } \\
\hline & & Face 1 & Face 2 & $8 \mathrm{~mm}$ & $15 \mathrm{~mm}$ & $22 \mathrm{~mm}$ & $8 \mathrm{~mm}$ & $15 \mathrm{~mm}$ & $22 \mathrm{~mm}$ \\
\hline $1 S$ & 0.4 & 10 & 0 & 0.75 & 0.97 & 1.06 & -0.79 & -0.99 & -1.08 \\
\hline 1D & 0.4 & 10 & 10 & 1.05 & 1.22 & 1.34 & -1.01 & -1.21 & -1.32 \\
\hline $2 S$ & 0.4 & 10 & 0 & 0.83 & 1.07 & 1.12 & -0.8 & -0.92 & -0.95 \\
\hline $2 \mathrm{D}$ & 0.4 & 10 & 10 & 1.09 & 1.26 & 1.38 & -1.12 & -1.29 & -1.4 \\
\hline $3 S$ & 1.2 & 10 & 0 & 3.58 & 3.72 & 3.77 & -3.33 & -3.64 & -3.78 \\
\hline $3 \mathrm{D}$ & 1.2 & 10 & 10 & 3.87 & 4.27 & 4.25 & -4.14 & -4.61 & -4.57 \\
\hline $4 S$ & 1.2 & 10 & 0 & 3.22 & 3.66 & 3.84 & -3.49 & -3.84 & -3.92 \\
\hline 4D & 1.2 & 10 & 10 & 5.51 & 6.2 & 6 & -4.8 & -5.1 & -5 \\
\hline $5 S$ & 1.2 & 10 & 0 & 3.16 & 3.41 & 3.6 & -3.06 & -3.2 & -3.5 \\
\hline $5 \mathrm{D}$ & 1.2 & 10 & 10 & 5.7 & 6 & 6.5 & -5 & -5.67 & -6 \\
\hline $6 S$ & 1.2 & 10 & 0 & 3.62 & 4.04 & 4.2 & -3.37 & -3.96 & -4.06 \\
\hline $6 \mathrm{D}$ & 1.2 & 10 & 10 & 5.51 & 6.05 & 5.75 & -5 & -5.44 & -5.35 \\
\hline
\end{tabular}

Note: The first digit of the test names is the number of the pair group, D means both faces are sheathed with plasterboard and $S$ means only one face is sheathed with plasterboard.

A great deal of effort has been made on load sharing when using different sheathing sheets on both faces. However, these studies were mainly conducted overseas, and they focused on load sharing between plasterboard and OSB (oriented strand board) or similar wood-based panel sheets [10-15]. All these studies, except the study by Chen, Chui, Doudak and Nott [15], have concluded that the load sharing between different sheathing sheets depends on the sheet properties and fastener details and that sheathing sheets of significantly different stiffnesses would have limited load sharing. Specifically, stiffer sheets, like plasterboard, resist most of the applied load until they fail. After the stiffer boards fail, all the load is resisted by the more ductile sheets (OSB or plywood).
In the study by Chen et al. [15], 12 shear walls sheathed with OSB alone, plasterboard only or a combination of OSB and plasterboard were tested under monotonic or reversed cyclic lateral load. It is noted that the end studs and the bottom plates of the test specimens were firmly bolted down to the rigid foundation beams. The test programme concluded that the direct superposition rule can be used to estimate the overall strength of a shear wall sheathed with OSB on one side and plasterboard on the opposite side.

The P21 test results listed in Table 1 are used for studying load sharing between single-sided and double-sided plasterboard walls as typical of NZ practice. Table 2 summarises the racking strength improvement when the wall had sheathing on both 
faces in comparison with the identical wall but with one face lined only. Figure 7 graphically shows the obtained hysteresis loops of the paired specimens.

If direct superposition rule applies, the test labelled \#D in each pair group should have a doubled racking strength of the counterpart test labelled as \#S. As shown in Table 2 and illustrated in Figure 7, the sheathing on the second face led to improved bracing strength in comparison with the singly sheathed counterparts, and the enhancement varies between $15 \%$ and $70 \%$. Clearly, the bracing enhancement resulting from the sheathing on the second face as typical of NZ practice is much lower than the predictions from direct superposition as suggested by Chen et al. [15]. Significant differences between the tests by Chen et al. and the tests used in this study include the connections between bottom plates and the end studs as well as the hold-down details from bottom plates to the foundations. The comparative studies described above suggest that the deformation within the timber frames and the deformations attributed to the uplift at wall bases might have contributed significantly to the wall flexibilities.

Table 2: Racking strength improvement due to the sheathing of the second face.

\begin{tabular}{|c|c|c|c|c|c|c|c|c|c|}
\hline \multirow{2}{*}{$\begin{array}{l}\text { Test } \\
\text { Names }\end{array}$} & \multirow[b]{2}{*}{ Length $(\mathrm{m})$} & \multicolumn{2}{|c|}{$\begin{array}{c}\text { Plasterboard } \\
\text { thickness }(\mathrm{mm})\end{array}$} & \multicolumn{3}{|c|}{ Racking capacity (+) (kN) } & \multicolumn{3}{|c|}{ Racking capacity (-) (kN) } \\
\hline & & Face 1 & Face 2 & $8 \mathrm{~mm}$ & $15 \mathrm{~mm}$ & $22 \mathrm{~mm}$ & $8 \mathrm{~mm}$ & $15 \mathrm{~mm}$ & $22 \mathrm{~mm}$ \\
\hline $1 S$ & 0.4 & 10 & 0 & 0.75 & 0.97 & 1.06 & -0.79 & -0.99 & -1.08 \\
\hline 1D & 0.4 & 10 & 10 & 1.05 & 1.22 & 1.34 & -1.01 & -1.21 & -1.32 \\
\hline \multicolumn{4}{|c|}{ Improvement } & $40 \%$ & $26 \%$ & $26 \%$ & $28 \%$ & $22 \%$ & $22 \%$ \\
\hline $2 S$ & 0.4 & 10 & 0 & 0.83 & 1.07 & 1.12 & -0.8 & -0.92 & -0.95 \\
\hline 2D & 0.4 & 10 & 10 & 1.09 & 1.26 & 1.38 & -1.12 & -1.29 & -1.4 \\
\hline \multicolumn{4}{|c|}{ Improvement } & $24 \%$ & $15 \%$ & $19 \%$ & $29 \%$ & $29 \%$ & $32 \%$ \\
\hline $3 S$ & 1.2 & 10 & 0 & 3.58 & 3.72 & 3.77 & -3.33 & -3.64 & -3.78 \\
\hline 3D & 1.2 & 10 & 10 & 3.87 & 4.27 & 4.25 & -4.14 & -4.61 & -4.57 \\
\hline \multicolumn{4}{|c|}{ Improvement } & $8 \%$ & $15 \%$ & $13 \%$ & $24 \%$ & $27 \%$ & $21 \%$ \\
\hline $4 \mathrm{~S}$ & 1.2 & 10 & 0 & 3.22 & 3.66 & 3.84 & -3.49 & -3.84 & -3.92 \\
\hline 4D & 1.2 & 10 & 10 & 5.51 & 6.2 & 6 & -4.8 & -5.1 & -5 \\
\hline \multicolumn{4}{|c|}{ Improvement } & $71 \%$ & $69 \%$ & $56 \%$ & $38 \%$ & $33 \%$ & $28 \%$ \\
\hline $5 S$ & 1.2 & 10 & 0 & 3.16 & 3.41 & 3.6 & -3.06 & -3.2 & -3.5 \\
\hline 5D & 1.2 & 10 & 10 & 5.7 & 6 & 6.5 & -5 & -5.67 & -6 \\
\hline \multicolumn{4}{|c|}{ Improvement } & $80 \%$ & $76 \%$ & $81 \%$ & $63 \%$ & $77 \%$ & $71 \%$ \\
\hline $6 \mathrm{~S}$ & 1.2 & 10 & 0 & 3.62 & 4.04 & 4.2 & -3.37 & -3.96 & -4.06 \\
\hline $6 \mathrm{D}$ & 1.2 & 10 & 10 & 5.51 & 6.05 & 5.75 & -5 & -5.44 & -5.35 \\
\hline \multicolumn{4}{|c|}{ Improvement } & $52 \%$ & $50 \%$ & $37 \%$ & $48 \%$ & $37 \%$ & $32 \%$ \\
\hline
\end{tabular}

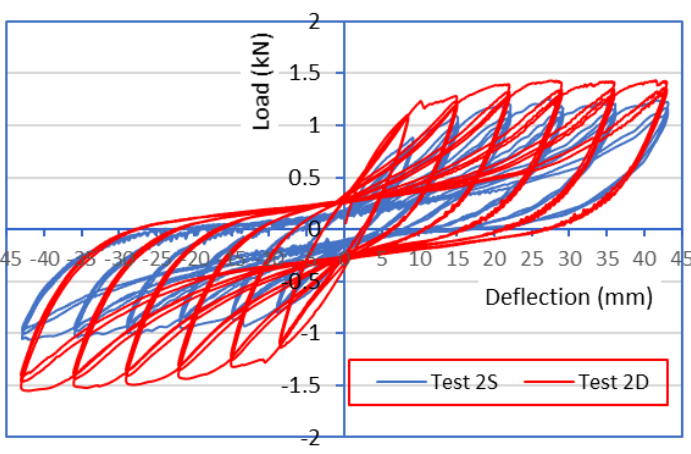

$0.4 \mathrm{~m}$ long

(a) Test $2 S$ and Test $2 D$

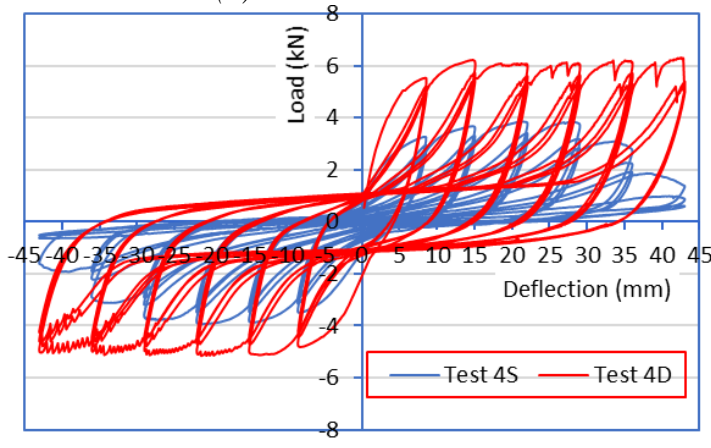

$1.2 \mathrm{~m}$ long

(c) Test $4 S$ and Test $4 D$

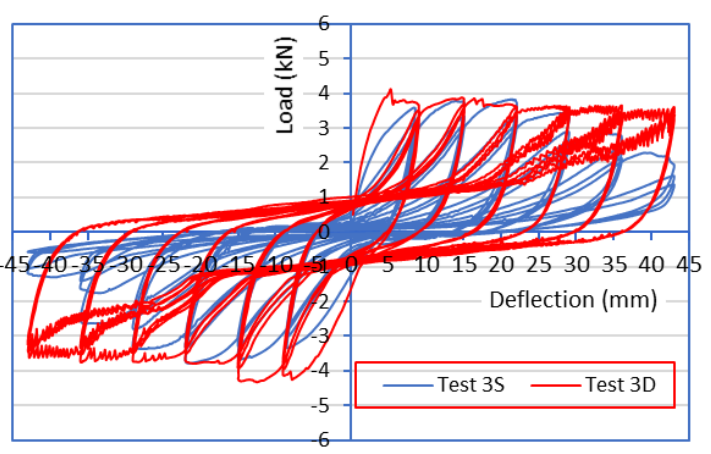

$1.2 \mathrm{~m}$ long

(b) Test $3 S$ and Test $3 D$

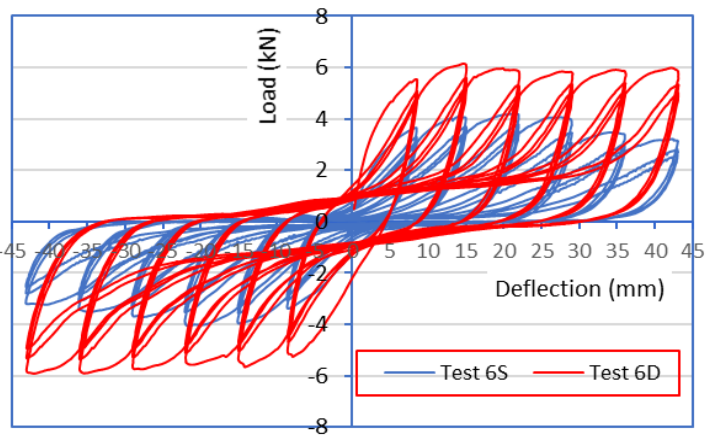

$1.2 \mathrm{~m}$ long

(d) Test 65 and Test $6 D$

Figure 7: Hysteresis loops of paired P21 tests obtained at BRANZ. 
There are no test results available for studying the effect of frame deformation on the overall wall flexibility. However, one pair of P21 tests in Table 1, Test 3S and Test 3D, had the uplift movement measurements, and the results were used to provide insight into the contributions of uplift to the overall deflections. Figure 8 shows the contributions of uplift to the total deflections for these two $1.2 \mathrm{~m}$ long walls.

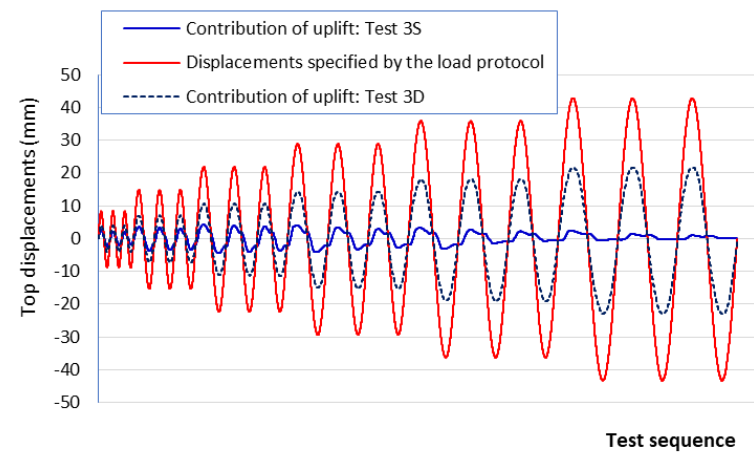

\section{Figure 8. Contribution of uplift and overall horizontal deflections (Test 3S and Test 3D).}

As illustrated in Figure 8, the uplift contribution to the horizontal deflection of the doubly lined wall could be up to $43 \%$ of total deflection, and it is much greater than that of the otherwise identical wall but with a single lining. When both faces of the wall are lined, the sheathing provides much more resistance, increasing the demand for hold-downs and leading to significantly greater uplift contribution. This is to say that, should the hold-down of a wall be enhanced significantly, the racking performance of a doubly lined wall would be closer to that predicted using the superposition laws. On this basis, it could be deduced that the seismic performance of a bracing wall on a suspended timber floor could be different from that on a concrete foundation. This also suggests that the P21 test procedure could be improved to quantify the effect of uplifts for different proprietary wall systems. This will help the proprietary system suppliers to improve their systems and eventually help achieve more consistent seismic performance of LTF buildings.

\section{Strength Degradation as Cyclic Loading Progresses}

In conducting P21 tests on LTF walls, the loading is a displacement-controlled procedure. At each specified deflection level, three cycles are applied. P21 tests on plasterboard walls always show significant degradations of racking strength and energy-dissipating capacities as cyclic loading progresses.

Table 3 lists the attained racking strength of six P21 tests during the first cycle and the third cycle at specific deflection levels.

Table 3: Racking strength attainments.

\begin{tabular}{|c|c|c|c|c|c|c|c|}
\hline \multirow[t]{2}{*}{ Test names } & \multirow[t]{2}{*}{ Cycle \# } & \multicolumn{6}{|c|}{ Racking strength $(\mathrm{kN})$ at specific deflection levels } \\
\hline & & $8 \mathrm{~mm}$ & $15 \mathrm{~mm}$ & $22 \mathrm{~mm}$ & $29 \mathrm{~mm}$ & $36 \mathrm{~mm}$ & $43 \mathrm{~mm}$ \\
\hline \multirow[t]{2}{*}{ 2D } & 1st cycle & $1.1(-1.1)$ & $1.3(-1.3)$ & $1.4(-1.4)$ & $1.4(-1.5)$ & $1.4(-1.5)$ & $1.4(-1.6)$ \\
\hline & 3rd cycle & $1.1(-1.1)$ & $1.2(-1.2)$ & $1.3(-1.3)$ & $1.3(-1.4)$ & $1.3(-1.4)$ & $1.3(-1.4)$ \\
\hline \multirow[t]{2}{*}{$4 S$} & 1st cycle & $3.2(-3.5)$ & $3.7(-3.6)$ & $3.8(-3.9)$ & $3.8(-3.8)$ & $3.1(-3.1)$ & $1.9(-1.9)$ \\
\hline & 3rd cycle & $2.8(-3.0)$ & $3.1(-3.2)$ & $3.2(-3.2)$ & $2.8(-2.9)$ & $1.9(-1.9)$ & $0.6(-0.5)$ \\
\hline \multirow[t]{2}{*}{$4 \mathrm{D}$} & 1st cycle & $5.5(-4.8)$ & $6.2(-5.1)$ & $6.1(-5.0)$ & $6.1(-5.1)$ & $6.2(-5.1)$ & $6.3(-5.0)$ \\
\hline & 3rd cycle & $5.0(-4.3)$ & $5.5(-4.5)$ & $5.3(-4.5)$ & $5.4(-4.5)$ & $5.3(-4.6)$ & $5.2(-4.7)$ \\
\hline \multirow[t]{2}{*}{$5 S$} & 1st cycle & $3.2(-3.1)$ & $3.4(-3.2)$ & $3.6(-3.5)$ & $3.6(-3.5)$ & $3.5(-3.3)$ & $3.2(-3.0)$ \\
\hline & 3rd cycle & $2.6(-2.6)$ & $2.9(-2.9)$ & $3.1(-3.0)$ & $2.9(-2.9)$ & $2.8(-2.6)$ & $2.5(-2.3)$ \\
\hline \multirow[t]{2}{*}{$5 \mathrm{D}$} & 1st cycle & $5.7(-4.9)$ & $6.0(-5.7)$ & $6.5(-6.0)$ & $6.8(-5.9)$ & $6.8(-5.9)$ & $5.9(-5.2)$ \\
\hline & 3rd cycle & $4.9(-4.6)$ & $5.4(-5.1)$ & $5.7(-5.2)$ & $5.8(-5.1)$ & $5.6(-4.8)$ & $4.4(-4.0)$ \\
\hline \multirow[t]{2}{*}{$6 S$} & 1st cycle & $3.6(-3.4)$ & $4.1(-4.0)$ & $4.2(-4.1)$ & $4.1(-3.7)$ & $3.5(-3.5)$ & $3.2(-3.2)$ \\
\hline & 3rd cycle & $3.1(-2.9)$ & $3.5(-3.3)$ & $3.5(-3.2)$ & $3.1(-3.0)$ & $2.8(-2.9)$ & $2.6(-2.5)$ \\
\hline
\end{tabular}

Note: Racking strength outside brackets and inside brackets are respectively the attained racking strength in positive and negative loading directions.

As seen in Table 3, the racking strength attained at the third cycle is significantly lower than the racking strength attained at the first cycle for the same deflection level, and the degradation increases as the deflection level increases. For the $22 \mathrm{~mm}$ level, the decrease ranges from about $10 \%$ to $25 \%$.

\section{Energy Dissipating Capacity of Typical Plasterboard Wall Elements}

Energy-dissipating performance of primary lateral loadresisting systems of a building is an important factor to be considered in its seismic design and thus the energy-dissipating capacities of plasterboard walls are studied.

There are many methods available to calculate equivalent damping levels. One common method used in estimating damping level is the method developed by Jacobsen [16]. By using this method, the equivalent damping $\left(\xi_{e q}\right)$ is derived by equating the energy absorbed by hysteretic cyclic response for a given displacement level and expressed as follows:

$\xi_{e q}=\frac{A_{h}}{2 \pi F_{m} \Delta_{m}}$

where:

$A_{h}$ is the area within one complete cycle of a stablised forcedisplacement response

$F_{m}$ and $\Delta_{m}$ are the maximum force and displacement achieved in the stablised loops.

As illustrated in Figure 7, the force-displacement hysteresis loops of plasterboard walls showed significant degradation at the loading cycles at each specific deflection level. In this study, the damping levels are estimated using the complete first cycle and the complete third cycle. 
Estimated damping of four representative P21 tests are listed in Table 4. The damping derived from the first cycle averages about $15 \%$ at low deflection levels and $10 \%$ at high deflection levels. In comparison, the average damping at the third cycle dropped to about $10 \%$ and $6 \%$ for low deflection levels and high deflection levels, respectively. For the plasterboard walls in Table 4, the seismic bracing ratings obtained from P21 tests were the bracing strengths of the walls sustained at the $22 \mathrm{~mm}$ deflection level. The damping at the deflection level of $22 \mathrm{~mm}$ is about $13 \%$ for the first cycle and reduces to $8 \%$ for the third cycle.

Based on an elemental-based approach, a system with a damping ratio of $8 \%$ to $13 \%$ would translate to an equivalent ductility of about 1.25 to 1.5 [7]. This reveals that the assumed ductility of 3.5 assumed for NZS 3604 significantly overestimates the energy-dissociating capacity of plasterboard walls.

Table 4: Damping ratios based on P21 test results.

\begin{tabular}{|c|c|c|c|c|c|c|c|}
\hline $\begin{array}{l}\text { Test } \\
\text { names }\end{array}$ & Cycle \# & $\begin{array}{l}8 \mathrm{~mm} \\
\text { cycle }\end{array}$ & $\begin{array}{l}15 \mathrm{~mm} \\
\text { cycle }\end{array}$ & $\begin{array}{l}22 \mathrm{~mm} \\
\text { cycle }\end{array}$ & $\begin{array}{l}29 \mathrm{~mm} \\
\text { cycle }\end{array}$ & $\begin{array}{c}36 \mathrm{~mm} \\
\text { cycle }\end{array}$ & $\begin{array}{l}43 \mathrm{~mm} \\
\text { cycle }\end{array}$ \\
\hline \multirow[b]{2}{*}{$4 S$} & 1st & $18 \%$ & $14 \%$ & $13 \%$ & $12 \%$ & $11 \%$ & $10 \%$ \\
\hline & 3rd & $10 \%$ & $9 \%$ & $9 \%$ & $8 \%$ & $8 \%$ & $6 \%$ \\
\hline \multirow[b]{2}{*}{$4 \mathrm{D}$} & $1 \mathrm{st}$ & $19 \%$ & $15 \%$ & $13 \%$ & $11 \%$ & $9 \%$ & $8 \%$ \\
\hline & 3rd & $10 \%$ & $9 \%$ & $8 \%$ & $7 \%$ & $6 \%$ & $6 \%$ \\
\hline \multirow[b]{2}{*}{$5 S$} & $1 \mathrm{st}$ & $15 \%$ & $14 \%$ & $13 \%$ & $12 \%$ & $10 \%$ & $9 \%$ \\
\hline & 3rd & $10 \%$ & $10 \%$ & $9 \%$ & $8 \%$ & $7 \%$ & $7 \%$ \\
\hline \multirow[b]{2}{*}{$5 \mathrm{D}$} & 1st & $15 \%$ & $14 \%$ & $13 \%$ & $11 \%$ & $11 \%$ & $11 \%$ \\
\hline & 3rd & $10 \%$ & $9 \%$ & $9 \%$ & $9 \%$ & $9 \%$ & $8 \%$ \\
\hline
\end{tabular}

\section{Racking Performance Model of Timber Walls Typical of NZ Practice}

There are a few racking models developed overseas and in NZ to describe the racking performance of sheathed LTF walls. These models can be broadly classified into two main categories, namely closed-form mathematical models and finite element models (FEM). These two types of model are different. Closed-form mathematical models describe the overall bracing action versus lateral deflection response of a wall without comprehensively analysing each component in a wall system. In contrast, FEM models simulate each individual component within a wall, such as nails, sheathing, studs and hold-down elements and so on. In a typical FEM model, the loaddeformation hysteresis behaviour of each individual component of a wall is mathematically defined.

The closed-form mathematical modelling approach was attempted by many researchers, such as Tuomi and McCutcheon [17], Easley, Foomani and Dodds [18], Gupta and Kuo [19], McCutcheon [20], Patton-Mallory and McCutcheon [21], Murakami, Moss, Carr and Inayama [22] and Salenikovich [23]. All these efforts considered timber walls with wood-based sheathing materials (for example, plywood and OSB) as typically used in the United States. A racking model developed in NZ by Dowrick and Smith [24] was also a closed-form solution and was developed for rectangular plywood shear walls. In this method, the overall deflection of a timber wall was considered to have four components: flexural deformation, shear deformation, uplift-related deflection and slip-induced deflection. Each component is calculated using a closed-form mathematical formula. The only closed-form racking model of plasterboard walls was developed by Liew, Gad and Duffield [25], based on Australian residential practice, which is different from NZ practice. In Liew et al.'s model, the load-slip behaviour of the fasteners is formulated first, and the total strain energy of the fasteners and the studs is set to be in equilibrium with the work done by the external force. Generally, these closed-form mathematical models are developed for the applications of rectangular-shaped LTF walls.

As explained before, FEM models are comprehensive and require much greater effort. FE modelling solutions are mainly used by researchers. For instance, Gutkowski and Castillo [26], Dolan [27], Kasal, Leichti and Itani [28] and Folz and Filiatrault
[29] successfully developed racking wall models for different applications using FE formulations. These models were developed and verified for timber walls with wood-based sheathing sheets. Due to the onerous nature, FEM analysis techniques have very little use in engineering practice of LTF buildings.

Plasterboard walls have different racking responses from woodbased timber walls, as revealed from P21 tests. For timber walls sheathed using plywood or other wood-based sheathing sheets, significant movements occur between sheets during the racking test of a wall. In contrast, plasterboard during a racking test behaves like one single plate element. Clearly, a mathematical model developed based on timber walls with wood-based sheathing is not suitable for modelling plasterboard walls. An appropriate mathematical model for plasterboard walls as typical in NZ practice needs to be developed for studying seismic performance of NZ residential buildings. In this study, a model is developed based on P21 test results on plasterboard walls as typical of NZ residential LTF construction. Noted is that the developed model has not allowed for the effects of confinements provided by the surrounding structural systems because of the lack of the test results.

\section{Development of a Closed-form Racking Model of NZ Plasterboard Walls}

Over the years, many P21 tests on plasterboard walls have been conducted in NZ. However, the measurements obtained during P21 tests are limited and insufficient to distinguish contributions of different mechanisms to total deformations. A closed-form racking performance envelope (skeleton) model is considered as a solution for plasterboard walls typical of NZ practice. Such a model can be used for conducting non-linear push-over studies of LTF buildings in earthquakes.

In developing the closed-form racking model, one consideration is the need for simulating plasterboard walls of different configurations in order to predict the seismic performance of an LTF building realistically. Also considered in developing the racking model is the proximity of the developed model to other wall modelling techniques in engineering practice, such as shell elements or plate elements for reinforced concrete walls.

Bearing in mind these requirements, a closed-form mathematical model for plasterboard bracing walls is suggested 
to simulate the non-linear behaviour using degrading material properties. The equivalent material properties in relation to the proposed racking models are then calibrated from the test results.

\section{Deformation Mechanisms of Typical NZ Plasterboard Walls}

A conceptual deformation mechanism study of plasterboard walls was conducted in this study as part of the modelling development. It was assumed that the lateral in-plane deflection at the top of a cantilevered rectangular plasterboard wall consists of four components, similar to plywood walls without relative movements between sheets. The expression is as follows:

$\Delta_{\text {total }}=\Delta_{\text {flexural }}+\Delta_{\text {shear }}+\Delta_{\text {slip }}+\Delta_{\text {uplift }}$

where:

$\Delta_{\text {flexural }}=2 \mathrm{VH}^{3} /\left(3 \mathrm{E} \mathrm{A}_{\mathrm{c}} \mathrm{L}^{2}\right)$ and is the contribution to the horizontal deflection due to bending deformation of the wall. $\mathrm{V}$ is the racking load at top of the wall, $\mathrm{H}$ is the height of the wall assembly, E is the modulus of elasticity of timber chords and it is $8 \mathrm{GPa}$ for SG8 [4], $\mathrm{Ac}_{\mathrm{c}}$ is the area of chord and is $4050 \mathrm{~mm}^{2}$, which is the cross-sectional area of a $90 \times 45 \mathrm{~mm}$ timber stud, and $\mathrm{L}$ is length of the wall assembly.

$\Delta_{\text {shear }}=\mathrm{H} /(\mathrm{Gt}) \mathrm{V} / \mathrm{L}$ and is the shear deformation component. The shear resistance is primarily provided by plasterboard sheathing. $G$ is the shear modulus of plasterboard sheet and $t$ is the total thickness of the sheet.

$\Delta_{\text {slip }}=\mathrm{C}_{1} \mathrm{~V} / \mathrm{L}$ and is the deformation component attributed to screw slip and $C_{1}$ is a coefficient. Plasterboard sheets have no relative movements between sheets. $\Delta_{s l i p}$ is proportional to the shear actions in screws.
$\Delta_{\text {uplift }}=\mathrm{C}_{2} \mathrm{H} \mathrm{V} / \mathrm{L}$ and is proportional to the product of the applied force and the aspect ratio of the wall. $\mathrm{C}_{2}$ is a coefficient. Similar to slip contribution, expression of uplift shares similarity to that of shear deformation mechanism.

In summary, except for the flexural deformation component, all other deformation components are proportional to the shear action per unit wall length, similar to the shear mechanism. As such, the total deformation is grouped into two types - one is the flexural deformation and the other is the equivalent shear deformation, $\Delta_{s s u}$, which is the combined deformation due to screw slip, shear and uplift.

The total lateral deflection is then expressed as:

$\Delta_{\text {total }}=\Delta_{\text {flexural }}+\Delta_{\text {ssu }}$

where the combined deformation, $\Delta_{s s u}$, becomes:

$\Delta_{s s u}=\mathrm{VH} /\left(\mathrm{G}_{\mathrm{e}} \mathrm{Lt}_{\mathrm{e}}\right)$

where:

te is the effective thickness of plasterboard sheathing, and it is taken as the thickness of sheathing if the walls are singly lined and is taken as the sum of the thicknesses of the sheathing sheets if the walls have linings on both faces

$\mathrm{G}_{\mathrm{e}}$ is the equivalent shear modulus, which combines the effects of shear and slip deformations within the plasterboard as well as the uplift at the wall base.

Flexural deformation of the wall is very small and is ignored. The non-linear performance of plasterboard walls is simulated by the degradation of the equivalent shear modulus as the loading progresses. $\mathrm{G}_{\mathrm{e}}$ can be calibrated based on test results.

Based on P21 test results and the method described above, calibrated shear modulus values for each test in Table 1 are illustrated in Figure 9.

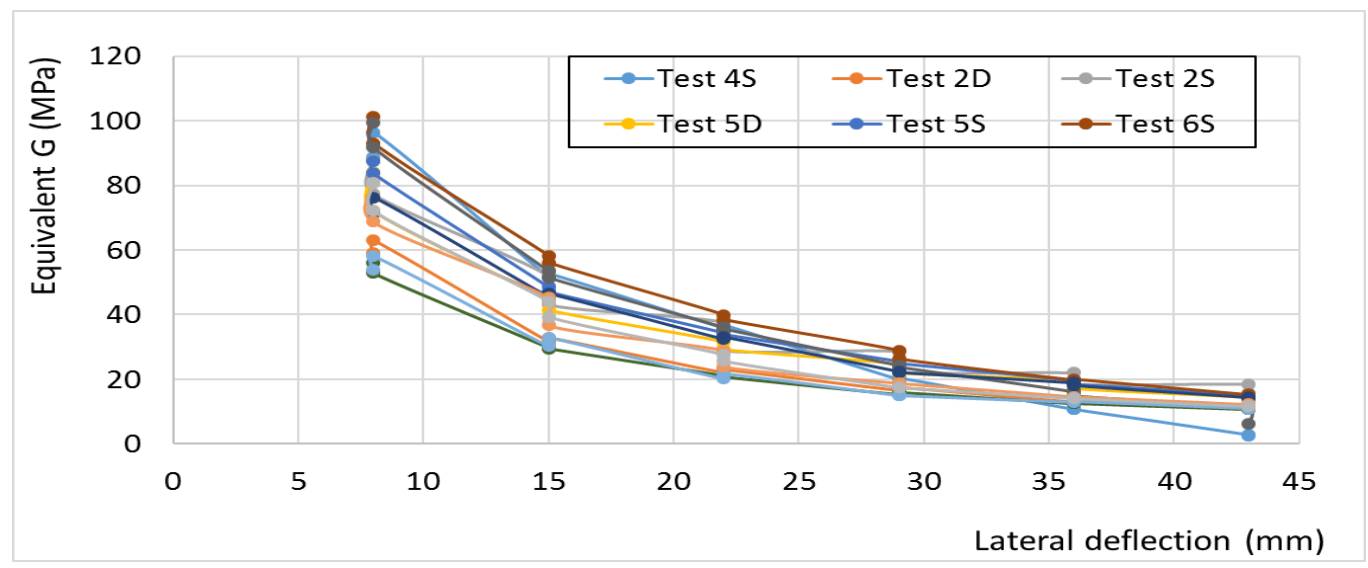

Figure 9: Calibrated shear modulus based on the P21 tests.

The equivalent shear modulus values at different deflection levels are derived subsequently and are listed in Table 5 .

Table 5: Equivalent shear modulus (G in MPa).

\begin{tabular}{|c|c|c|c|c|c|}
\hline $\begin{array}{l}8 \mathrm{~mm} \\
\text { cycle }\end{array}$ & $\begin{array}{l}15 \mathrm{~mm} \\
\text { cycle }\end{array}$ & $\begin{array}{c}22 \mathrm{~mm} \\
\text { cycle }\end{array}$ & $\begin{array}{l}29 \mathrm{~mm} \\
\text { cycle }\end{array}$ & $\begin{array}{c}36 \mathrm{~mm} \\
\text { cycle }\end{array}$ & $\begin{array}{c}43 \mathrm{~mm} \\
\text { cycle }\end{array}$ \\
\hline $\begin{array}{c}90 \\
\mathrm{MPa}\end{array}$ & $\begin{array}{c}50 \\
\mathrm{MPa}\end{array}$ & $\begin{array}{c}35 \\
\mathrm{MPa}\end{array}$ & $\begin{array}{c}25 \\
\mathrm{MPa}\end{array}$ & $\begin{array}{c}18 \\
\mathrm{MPa}\end{array}$ & $\begin{array}{c}15 \\
\mathrm{MPa}\end{array}$ \\
\hline
\end{tabular}

The backbone curves, derived using the shear modulus in Table 5 and the mathematical model as per Equation 5, provide a reasonably good match with the hysteresis loops obtained for P21 tests in Table 1, as illustrated in Figure 10.

The discrepancies between the numerical models and the test results in Figure 10 suggest that other factors, such as the uplift effect at the wall base, could affect the racking performance of the plasterboard walls, and further studies should be undertaken to refine the numerical model.

Figure 11 shows the backbone curves derived using the model with two P21 tests not included in developing the model. Clearly, they match the test results reasonably well. 


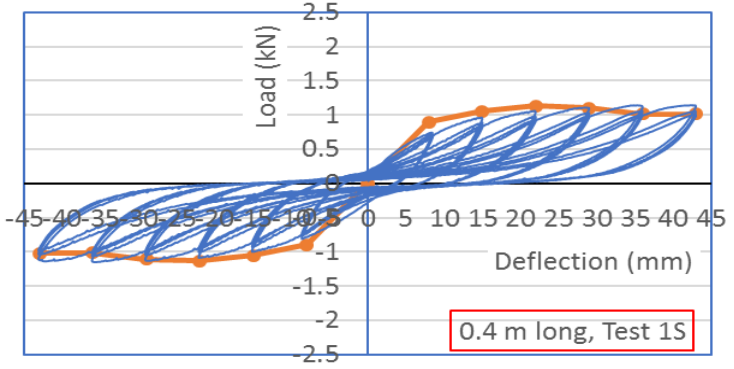

$\multimap$ model $\longrightarrow$ Test result

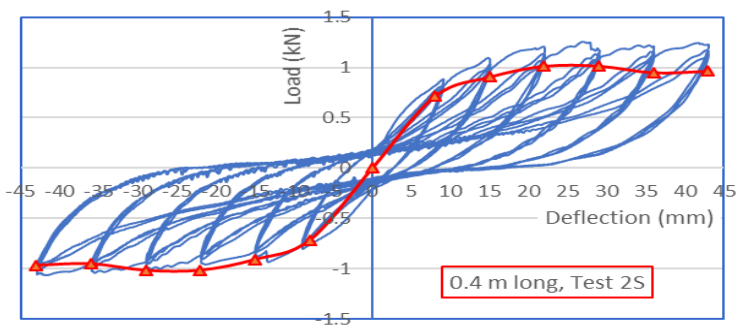

-Test results $\rightarrow$ Mode

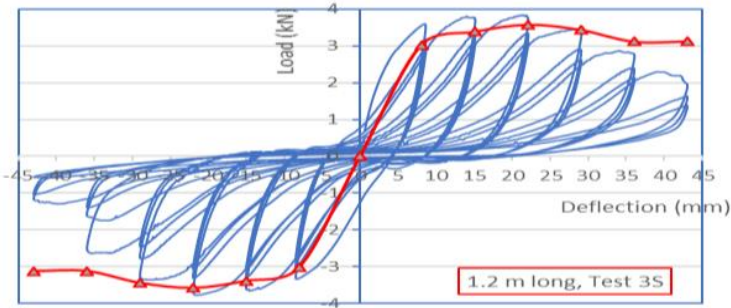

- Test results $\triangle \longrightarrow$ Model

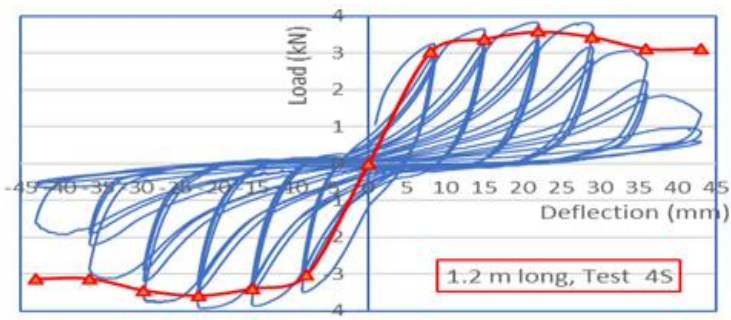

$\longrightarrow$ Test results $\longrightarrow$ Model

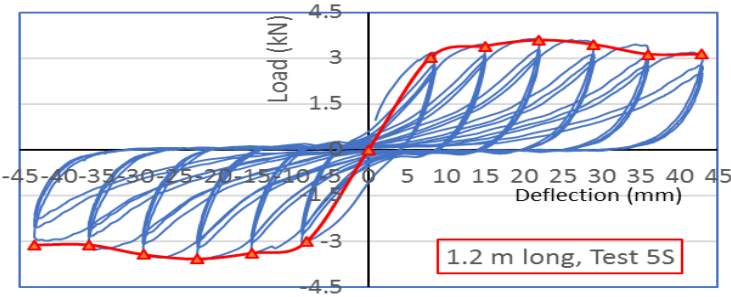

$\longrightarrow$ Test results $\triangle \longrightarrow$ Model

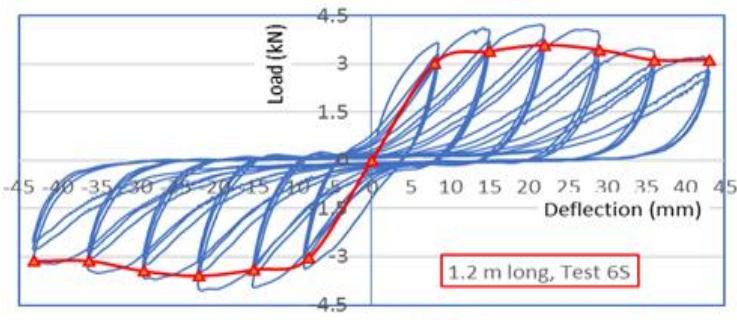

- Test results $\rightarrow$ Model

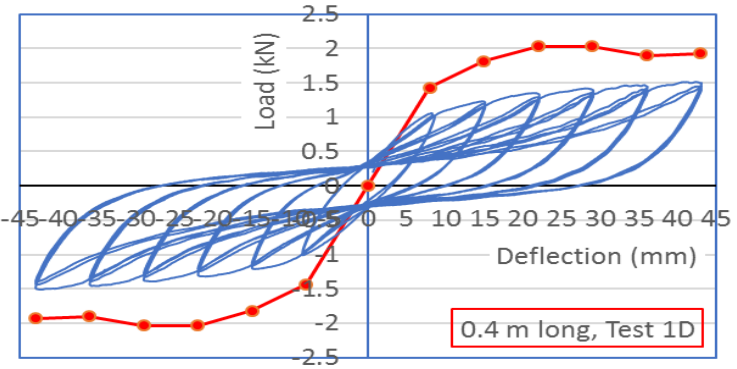

- - model — Test result

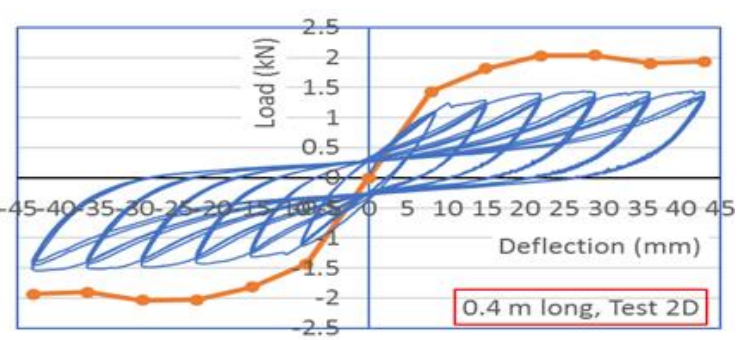

$\multimap$ model $\longrightarrow$ Test result

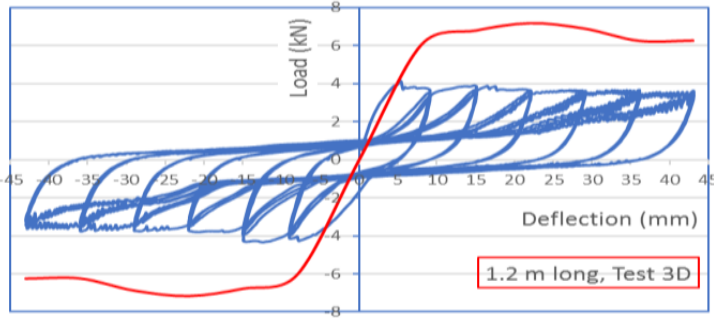

-Test results —Model

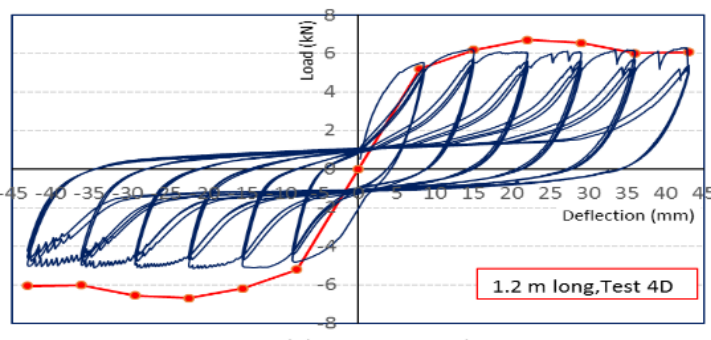

$\rightarrow$-model —Test Result
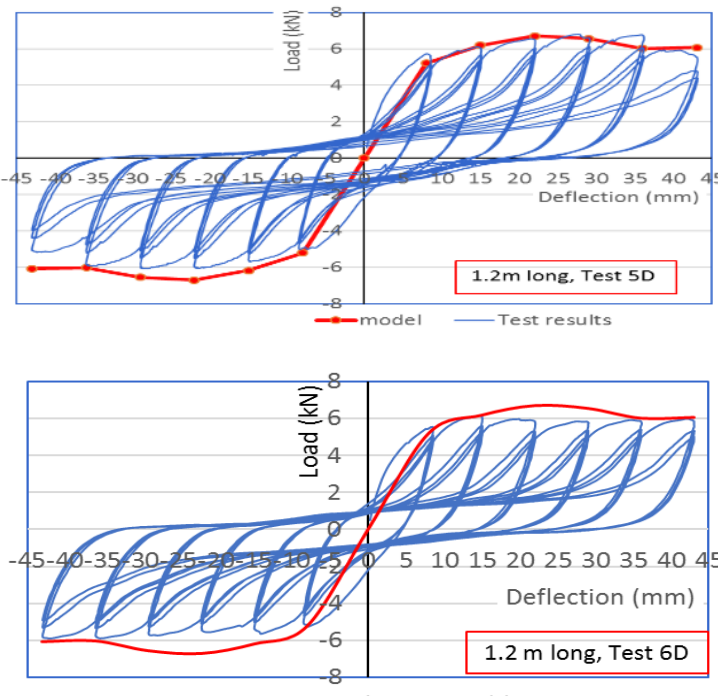

- Test result —Model

Figure 10: Test results versus the model developed. 


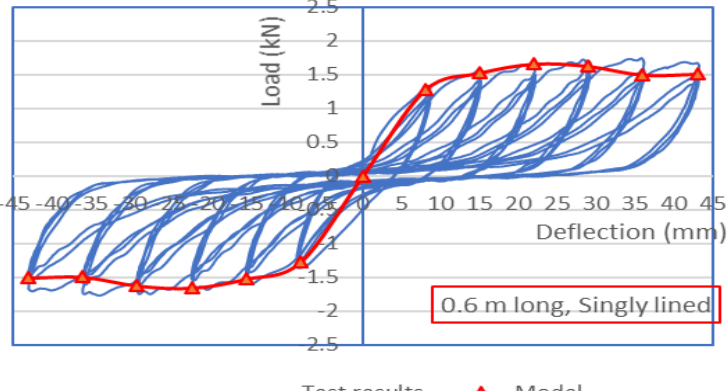

Figure 11: Test results of P21 tests versus the model developed.

\section{CONCLUSIONS}

In this paper, the racking performance of LTF plasterboard walls is studied as part of research efforts towards performancebased seismic engineering of NZ residential timber structures. The study was conducted using several racking test results with a focus on the racking performance characteristics of LTF plasterboard walls and the appropriate modelling techniques.

Results of the study are summarised as follows:

- Unlike ductile seismic resisting systems where the hysteresis loops are stable, LTF plasterboard walls are expected to have significant racking strength degradations as cyclic loading progresses at the same deflection levels. The analysis showed that the average racking strength attained at the third cycle is $15 \%$ to $25 \%$ lower than that attained at the first cycle for the same deflection level.

- Apart from racking strength degradation, LTF plasterboard walls are expected to have significant degradation in energy-dissipating capacity as cyclic loading progresses at the same deflection levels. The analysis showed that the equivalent damping levels are greater at lower deflection levels compared with that at higher levels.

- LTF plasterboard walls have limited energy dissipating capacity, and the maximum damping level derived is around $15 \%$. This is equivalent to a ductility of not greater than 2 in a force-based approach domain.

- Racking performance of plasterboard walls could potentially be enhanced by improving the connection details between timber frame members and/or by improving the hold-down details at wall bases.

- A closed mathematical model was developed based on the racking tests of plasterboard-clad LTF walls as typical of $\mathrm{NZ}$ practice. The developed model represents the walls as shell elements. The equivalent shear modulus of an LTF plasterboard wall degrades as the lateral deflections increase to reflect the degradation nature inherent in plasterboard-sheathed walls.

- The model development discussed in this paper is simple but crude, due to limited measurements of the P21 tests and limited wall configurations of the test specimens.

\section{ACKNOWLEDGEMENTS}

This research project was funded by the Building Research Levy. The authors would like to thank our colleagues, Roger Shelton and Graeme Beattie, for their constructive discussions.

\section{REFERENCES}

1 Priestley MJN, Calvi GM and Kowalsky MJ (2007). "Displacement-Based Seismic Design of Structures". IUSS Press, Italy.

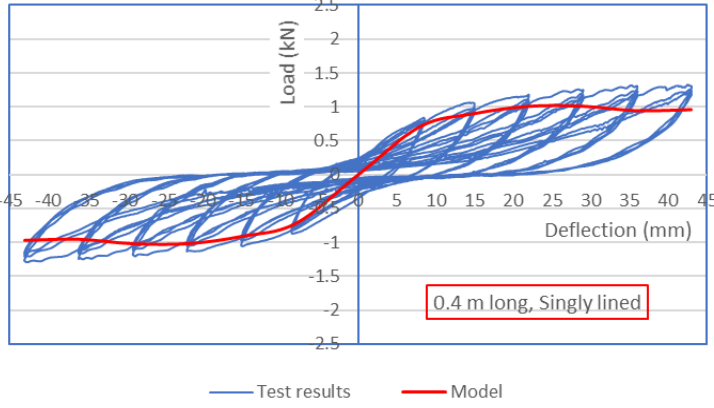

2 Bradley BA, Dhakal RP, Cubrinovski M, MacRae GA and Lee DS (2009). "Seismic Loss Estimation for Efficient Decision Making". Bulletin of the New Zealand Society for Earthquake Engineering, 42(2): 96-110.

3 Standards New Zealand (2011). "NZS 3604 Timberframed Buildings". Standards New Zealand, Wellington.

4 Shelton R (2013). "Engineering Basis of NZS 3604". BRANZ Ltd, Judgeford, New Zealand. http://www.branz.co.nz/Engineering_Basis_of_NZS_3604

5 Buchanan A, Carradine D, Beattie G and Morris H (2011). "Performance of Houses During the Christchurch Earthquake of 22 February 2011". Bulletin of the New Zealand Society for Earthquake Engineering, 44(4): 342357.

6 Bahmani P and van de Lindt JW (2013). "Direct Displacement Design of Vertically and Horizontally Irregular Woodframe Buildings". Proceedings of Structures Congress, Pittsburgh, USA, 2-4 May, 12171228.

7 Standards New Zealand (2004). "NZS 1170.5 Structural Design Actions - Part 5: Earthquake Actions - New Zealand". Standards New Zealand, Wellington.

8 Shelton R (2010). "A Wall Bracing Test and Evaluation Procedure". BRANZ Technical Paper P21. BRANZ Ltd, Judgeford, New Zealand.

http://www.branz.co.nz/P21

9 Liu A and Shelton R (2018). "Seismic Effects of Structural Irregularity of Light Timber-framed Buildings". BRANZ Study Report SR404. BRANZ Ltd, Judgeford, New Zealand.

10 Sinha A and Gupta R (2009). "Strain Distribution in OSB and GWB in Wood-frame Shear Walls". Journal of Structural Engineering, 135(6): 666-675.

11 Uang CM and Gatto K (2003). "Effects of Finish Materials and Dynamic Loading on the Cyclic Response of Woodframe Shearwalls. Journal of Structural Engineering, 129(10): 1394-1402.

12 Applied Technology Council (2012). "Seismic Evaluation and Retrofit of Multi-unit Wood-frame Buildings with Weak First Stories". FEMA P-807. Federal Emergency Management Agency, Washington, DC.

13 Filiatrault A and Folz B (2002). "Performance-based Seismic Design of Wood Framed Buildings". Journal of Structural Engineering, 128(1): 39-47.

14 Wolfe RW (1983). "Contribution of Gypsum Wallboard to the Racking Resistance of Light-frame Walls". FPL 439, Forest Products Laboratory, Forest Service, United States Department of Agriculture, Madison, WI.

15 Chen Z, Chui Y-H, Doudak G and Nott A (2016). "Contribution of Type-X Gypsum Wall Board to the Racking Performance of Light-frame Wood Shear Walls". 
Journal of Structural Engineering, 142(5): 04016008-104016008-12.

16 Jacobsen LS (1960). "Damping in Composite Structures". Proceedings of the Second World Conference on Earthquake Engineering, Tokyo and Kyoto, Japan, 11-18 July.

17 Tuomi RL and McCutcheon WJ (1978). "Racking Strength of Light Frame Nailed Walls". Journal of the Structural Division, 104(7): 1131-1140.

18 Easley JT, Foomani M and Dodds RH (1982). "Formulas for Wood Shear Walls". Journal of the Structural Division, 108(11): 2460-2478.

19 Gupta AK and Kuo GP (1985). "Behaviour of Woodframed Shear Walls". Journal of Structural Engineering, 111(8): 1722-1733.

20 McCutcheon WJ (1985). "Racking Deformations in Wood Shear Walls". Journal of Structural Engineering, 111(2): 257-269.

21 Patton-Mallory M and McCutcheon WJ (1987). "Predicting Racking Performance of Walls Sheathed on Both Sides". Forest Products Journal, 37(9): 27-32.

22 Murakami M, Moss PJ, Carr AJ and Inayama M (1999). "Formulae to Predict Non-linear Behaviour of Sheathed Walls with any Nailing Arrangement Pattern." Proceedings of the Pacific Timber Engineering Conference, Rotorua, New Zealand, 14-18 March, 189196.
23 Salenikovich AJ (2000). "The Racking Performance of Light-frame Shear Walls". PhD Thesis, Department of Wood Science and Forest Products, Virginia Polytechnic Institute and State University, Blacksburg, VA.

24 Dowrick DJ and Smith PC (1986). "Timber Sheathed Walls for Wind and Earthquake Resistance". Bulletin of the New Zealand National Society for Earthquake Engineering, 19(2): 123-134.

25 Liew YL, Gad EF and Duffield CF (2005). "Modularised Closed-form Mathematical Model for Predicting the Bracing Performance of Plasterboard Clad Walls". Structural Engineering and Mechanics, 20(1): 45-67.

26 Gutkowski RM and Castillo AL (1988). "Single and Double-sheathed Wood Shear Wall Study". Journal of Structural Engineering, 114(6): 1268-1284.

27 Dolan JD (1989). "The Dynamic Response of Timber Shear Walls". PhD Thesis, University of British Columbia Vancouver, Canada.

28 Kasal B, Leichti RJ and Itani RY (1994). "Nonlinear Finite Element Model of Complete Light Frame Wood Structures". Journal of Structural Engineering, 120(1): 100-119.

29 Folz B and Filiatrault A (2001). "CASHEW Version 1.0, A Computer Program for the Cyclic Analysis of Shear Walls". CUREE, Richmond, California. 